\title{
15. Trainees - the new army of cheap labour: Lessons from workfare Amir Paz-Fuchs
}

\subsection{INTRODUCTION}

Over the past decade or so, the status of trainees, apprentices and interns within the labour market has attracted an increased degree of attention. This is presumably owing, in part, to their sheer number within the labour market. A 2018 report in the United Kingdom (UK), for example, indicated that almost half (46 per cent) of employers offer graduate internships, with large employers twice as likely to do so as small businesses. ${ }^{1}$ It also found that the understanding that internships are an informal prerequisite is taking hold: 46 per cent of 21-23 year olds report they have completed an internship, compared with 37 per cent of 27-29 year olds. Of these, 70 per cent of internships are unpaid. This trend was noted by the 2017 Taylor Report commissioned by the UK government to review 'modern workplace practices'. ${ }^{2}$ The report recommended that 'the Government should ensure that exploitative unpaid internships, which damage social mobility in the UK, are stamped out. The Government should do this by clarifying the interpretation of the law and encouraging enforcement action taken by HMRC [Her Majesty's Revenue and Customs] in this area.' ${ }^{3}$ The government responded to the report with admirable rhetoric, noting that 'Exploitative unpaid internships should not exist and we will work to eradicate these'. ${ }^{4}$

As the number of internships grows significantly, a natural derivative is the concern that not all these positions live up to their putative rationales. In par-

1 Carl Cullinane and Rebecca Montacute, Pay As You Go? Internship Pay, Quality and Access in the Graduate Jobs Market (Sutton Trust 2018), https://www.suttontrust .com/wp-content/uploads/2019/12/Pay-As-You-Go-1.pdf, accessed 30 March 2021.

2 Matthew Taylor, Good Work: The Taylor Review of Modern Working Practices (Department for Business, Energy and Industrial Strategy 2017).

3 Ibid 91.

4 HM Government, Good Work: A Response to the Taylor Review of Modern Working Practices (HM Government 2018) 46. 
ticular, internships are said to address the joint problems of the spectacular rise in youth unemployment in some countries and the enduring complaint from employers that students graduate from the (secondary or higher) education system without the skills and knowledge to integrate smoothly into the workplace environment. The concerns, however, are that some, or perhaps most, modern-day training programmes do not address either of these problems, but instead serve as a source of free or cheap labour. In addition, assertions have been made that interns suffer ill treatment and mental stress, ${ }^{5}$ and that they are abused by employers, who fail to provide trainees with a true first step towards sustainable work. ${ }^{6}$ In these respects - the professed rationales and the scepticism towards their true and honest implementation - trainee schemes have much in common with workfare programmes, which have been discussed more widely. The term 'workfare' is used here in its narrow sense, as a sub-species within a wider group of programmes known as welfare-to-work. Developed originally in the United States of America (USA) and Australia, workfare schemes require claimants to work for their benefits ${ }^{7}$ or, with a slightly more critical gloss, condition public benefits on the performance of subpar employment. ${ }^{8}$ Where trainee schemes are, at times, referred to as 'open market internships', ${ }^{9}$ workfare schemes are sometimes discussed as active labour market policy internships. ${ }^{10}$ The similarities between the two types of programme run deep. Most pressingly, in both cases, participants may be excluded from a large range of employment protections, including the minimum wage.

Focusing on the UK and USA, this chapter shows that the justifications for this exclusion in both schemes are almost identical in the cases of interns and workfare participants (WPs), and serve to enhance each other's veracity. In particular, the (neoliberal) argument that both interns and WPs receive more than they offer is a prominent rationale for this exclusion.

5 Junior Lawyers Division, Resilience and Wellbeing Survey Report (Law Society 2018), http://communities.lawsociety.org.uk/Uploads/p/d/i/jld-resilience-and -wellbeing-survey-report-2018.pdf, accessed 30 March 2021.

6 Carole Lang, Isabelle Schömann and Stefan Clauwaert, 'Atypical Forms of Employment Contracts in Times of Crisis' (2013) ETUI Working Paper 2013.03, 21.

7 Amir Paz-Fuchs and Anja Eleveld, 'Workfare Revisited' (2016) 45 Indust LJ 29.

8 Amir Paz-Fuchs, 'Workfare's Persistent Philosophical and Legal Issues: Forced Labour, Reciprocity, and a Basic Income Guarantee' in Anja Eleveld, Thomas Kampen and Josien Arts (eds), Welfare to Work in Contemporary European Welfare States (Policy Press 2020).

9 See eg Paula McDonald, 'Open Market Internships: What Do Intermediaries Offer?’ (2020) 33(1) J Educ \& Work 33.

10 Andrew Stewart, Rosemary Owens, Anne Hewitt and Irene Nikoloudakis, 'The Regulation of Internships: A Comparative Study' (2018) ILO Employment Policy Department Working Paper No 240, ch 9. 
This insight is all the more important in light of the two schemes not being identical. Notwithstanding their similarities, there are important differences, some institutional and some ideological, which can shed some light on their structure and their constitution. First, workfare is organized and paid for by the government, often in collaboration with business. In contrast, internship programmes are regulated and sometimes (but not often) incentivized financially by governments, but are mainly initiated and organized by businesses. This distinction may plausibly underlie a different perception of, and attitude towards, those involved. The discourse around interns suggests that they have not been equipped with the necessary skills by the education system and therefore have to be, and deserve to be, assisted. The workfare narrative, however, seems to justify these schemes as aiding the participants only as an afterthought. Instead, WPs are asked to give back to the community which bestowed on them its generosity (the benefits), through their work participation, and the retrospective rationalization includes the argument that it is also good for them, as it is a step back into the employment market.

\subsection{WORKFARE AND INTERNSHIPS: COMMON MYTHS, COMMON REALITIES}

One of the enduring rationales presented in support of both workfare and internships is that the schemes are designed to benefit the participants, who seek (re)integration into the labour market. Where interns are concerned, the explanation is usually that on-the-job training is an excellent way for both parties to assess whether a future relationship would be attractive to both. The intern has the opportunity to discover whether the sector, and/or the particular employer, is what they had in mind for the first (or next) stage in their career. In addition, the intern acquires an important skill set, which will be beneficial in the future, 'a crucial bridge from being a college graduate to transitioning into the labour market'. ${ }^{11}$ However, the employer also has much to gain: as employers often explain, ${ }^{12}$ internships serve the purpose of (extremely) extensive interviews, and therefore are seen by businesses as part of their recruitment programme. The internship makes sure that the employer need not pay proper wages and offer a full package of benefits before the worker has acquired the relevant skill set. The on-the-job training is, therefore, at the intern's expense.

11 Kathryn Edwards and Alexander Hertel Fernandez, Paving the Way through Paid Internships: A Proposal to Expand Educational Opportunities for Low-Income College Students (Economic Policy Institute 2010) 3.

12 Eg Evan Davis, 'The Bottom Line: Internships' (BBC Radio 4, 16 March 2019), https://www.bbc.co.uk/programmes/m000360n, accessed 30 March 2021. 
In similar fashion, workfare programmes are billed as facilitating the reintegration of the long-term unemployed into the labour market. In contrast to interns, this is rarely seen as offering a particular skill set, but instead as contributing to the very basic level of human capital - instilling discipline and structure: the ability to get out of bed in the morning, the need to shave, dress up and arrive on time. Improving the capacities and capabilities of those outside, or on the fringes of, the labour market, is integral to the human-capital approach, which is particularly prevalent in European jargon. ${ }^{13}$

Yet, the contribution of workfare programmes to participants has been questioned. First, many of the long-term unemployed have had extensive job experience, and have been searching for work, sending curricula vitae (CVs) and going to interviews. They thus have little to no need for discipline-enhancement measures. Second, as Noah Zatz explains, while discipline and structure are fundamental to the successful completion of menial tasks, the modern workplace values and rewards traits such as creativity, spontaneity, flexibility, adaptability and risk-taking, which may be distinct from, and perhaps even in contrast to, discipline and structure. ${ }^{14}$ Indeed, the limited research on the matter does not provide evidence of successful reintegration into regular paid employment following participation in workfare. ${ }^{15}$

The previous description seems only partly to apply to interns. While they are seeking to enter the labour market, they do often lack experience, at least in the particular role for which they are aiming; and while WPs are expected to gain general employability skills (which, as mentioned, they may already have or not truly require), interns are expected to learn, through practice, the procedures and substance of the sector and the particular business. We find here, then, the limit of the internship scheme, namely, the extent to which the skills gained are transferable. The thousands of different schemes in the public and private sectors make it impossible to generalize but, to the extent that the participant integrates into the operating practice of the firm, and learns 'how to do things here', there is a good chance that this knowledge will be of less value elsewhere, and thus less transferable.

This description notwithstanding, we should not over-emphasize the differences between the two. In one American case, the court stressed that the benefit that interns received from their involvement in the scheme also included 'life lessons on the value of hard work' ${ }^{16}$ This may or may not be the case in reality, and we may question (for WPs and interns) the value of these

Anton Hemerijck, Changing Welfare States (OUP 2013) 142, 277.

Noah Zatz, 'What Welfare Requires from Work' (2006) 54 UCLA L Rev 373.

15 Amir Paz-Fuchs, Welfare to Work: Conditional Rights in Social Policy (OUP 2008) 173-200.

16 Solis v Laurelbrook Sanitarium and School 642 F 3d 518, 531 (6th Cir, 2011). 
'life lessons'. What is clear is that assuming that interns gain these life lessons serves an important legal purpose. I return to this point later.

Another interesting distinction between WPs and interns concerns the type of engagement. Workfare participants are often engaged in the most menial (blue-collar) jobs, whereas interns take on their role as a stepping stone towards white-collar positions, which are more diverse, require more skill or are better paid - and at times all of these. This is why we associate interns with sectors such as public relations, journalism and media, law, the civil service and the charity sector. Indeed, the problem associated with internships around the turn of the millennium was that they created one of the highest barriers to social mobility. ${ }^{17}$ In 2012, the UK Panel on Fair Access to the Professions noted that internships (here probably in their trainee variety) exclude entrants who are unwilling or unable to take unpaid work. ${ }^{18}$

Yet, simultaneously, a parallel problem was created, as internships began to spread from white- to blue- collar occupations in the (already) low-paid service economy. ${ }^{19}$ Thus, the National Trust was roundly criticized for advertising a six-month, unpaid Apple and Cider Internship involving working in the fields, picking and harvesting apples, and selling cider. ${ }^{20}$

If the assumptions that interns and WPs gain crucial skills and access to the employment market reveal themselves to be more myth than reality, another myth, which has legal implications, should now be addressed. According to this myth, it is primarily the intern, or WP, who benefits from the scheme, and not the business. Quite apart from the analytic and normative reasons to reject this cui bono ('who is the beneficiary?') test, which I address later, the myth should be regarded as just that, a myth, simply because it lacks empirical grounding. Instead, it is assumed that interns and WPs benefit far more from the scheme than the businesses or agencies involved. Without serious fieldwork, any observation cannot be more than hypothesizing, based on anecdotes. With that

17 Cullinane and Montacute (n 1).

18 Cabinet Office, Fair Access to Professional Careers: A Progress Report by the Independent Reviewer on Social Mobility and Child Poverty (Cabinet Office 2012).

19 Andrew Ross, No-Collar: The Humane Workplace and its Hidden Costs (Temple University Press 2004); Gregory Bergman, 'Unpaid Internships: A Tale of Legal Dissonance' (2014) 11 Rutgers J L \& Soc Pol 552.

20 David Lee, 'Internships, Workfare and the Cultural Industries: A British Perspective' (2015) 13 tripleC 459, 462; Chris Johnston, 'National Trust Criticised for Using Unpaid Interns to Do Admin Jobs' Guardian (London, 11 June 2016), https:// www.theguardian.com/uk-news/2016/jun/11/national-trust-criticised-for-using-unpaid -interns-to-do-admin-jobs, accessed 30 March 2021; Graduate Fog, 'Sorry, National Trust - But WTF is a "Cider and Apple Internship"?' (Graduate Fog, 31 July 2014), https:/graduatefog.co.uk/2014/3529/national-trust-internship-apple-cider/, accessed 30 March 2021. 
in mind, here are some of these anecdotes, from the USA and the UK. First, as regards WPs: a court in New York found that a work programme for homeless individuals incorporated participants as replacements for members of council staff who were late or absent, and even required them to work overtime or back-to-back shifts, generating revenue of $\$ 840000$ for the council. ${ }^{21}$ This is an instance of a widespread, global concern, whereby interns are replacing full-time employees and/or preventing others from entering the market. ${ }^{22}$ In the UK, local councils were found to have benefited from more than 500000 hours of unpaid labour through a back-to-work scheme in a variety of areas, including cleaning, rubbish collection, parks maintenance and library services. Although the councils denied that the participants in the scheme were deployed at the expense of employees, it was found that jobs were lost during the same period. John McArthur, whose position as a temporary worker was not extended, was sent to occupy his old position, as a participant in a back-to-work scheme, at no expense to the business, for six months. ${ }^{23}$

Businesses also benefit significantly from the incorporation of interns. First, even as an extensive and inexpensive 'graduate recruitment scheme' and training programme, it seems quite clear that internships are a cost-saving mechanism for businesses, avoiding the alternative route of taking a risk with a prospective employee only to find later that they are unsuitable; or through training the employee at the business's expense to gain the skills and competence which will enable them to secure the maximum profit for the business. Moreover, a recent report, based on a survey of over 1000 employers and over 2600 interns, ${ }^{24}$ suggests that either employers seem to benefit more than interns from internships or, at the very least, that there is a strong element of subjectivity in the assessment of 'benefit'. First, 70 per cent of employers responded that interns did 'useful work' in the business. ${ }^{25}$ More interestingly, however, the survey asked employers and interns to assess the quality and outcome of internships on the basis of five indicators, set by the Living Wage Foundation. The criteria are adequate training and monitoring, on-the-job rotation, a designated mentor or supervisor, a workplace learning plan and a post-internship follow-up. The differences in assessment are revealing: while 25 per cent of interns viewed their internships as exhibiting none of the indicators, the figure was 8 per cent for employers. Also, while 18 per cent of employers viewed

\footnotetext{
Archie v Grand Central Partnership 999 F Supp 504 (1998).

See Chapter 2 in this volume.

23 S Malik, 'DWP Orders Man to Work without Pay for Company that Let Him

Go', Guardian (London, 3 November 2014).

24 Cullinane and Montacute (n 1).

25 Ibid 41-2.
} 
their internships as meeting all of the criteria, a mere 2 per cent of interns felt the same way. ${ }^{26}$

It could be argued that the advantages of internships are less tangible, and that they contribute to the employment prospects of those undertaking them. This indeed is the common myth. In reality, however, there are indicators that unpaid internships are not only not beneficial; they may harm employment prospects. ${ }^{27}$ The previously mentioned report cites findings that completing an unpaid internship is 'associated with a salary penalty three years later', while its own survey suggests very moderate gains for those who took one unpaid internship, and those who did more than three unpaid internships ended up with salaries lower than those who did no internships at all. ${ }^{28}$ Similar figures are found in other jurisdictions. Thus, the American National Association of Colleges and Employers has found, over a period of three years, that 63 per cent of students with a paid internship received at least one job offer, while only 37 per cent of those who took unpaid internships were in the same position, a negligible 1.8 per cent more than those who did not intern at all. Again, those who performed unpaid internships received less pay than those with no internship experience. ${ }^{29}$ Now, it may well be argued that correlation is not causation (that is, it cannot be established that taking an unpaid internship leads to less beneficial prospects). Yet the study found that graduates who participated in unpaid internship schemes took similar degrees and had similar university grades to graduates who held paid internships. At the very least, it leaves a significant question mark hanging over the knee-jerk assumption that internships are, almost by definition, beneficial to interns, regardless of their characteristics.

We may argue against this insight, in that, if unpaid internships are detrimental to pay and job prospects, then the argument that they present a barrier to social mobility seems weaker. The Sutton Trust report suggests that the answer lies in the complexity of the world of internships. In particular, there is a 'two-track system', one of which is paid, openly advertised and provides opportunities, while the other offers no pay, training or development and leads from one internship to another, with negligible advantages, if at all, for eventual salaries. ${ }^{30}$

\footnotetext{
26 Ibid.

27 See Chapter 5 in this volume.

28 Cullinane and Montacute (n 1) 44.

29 Jordan Weissmann, 'Do Unpaid Internships Lead to Jobs? Not for College Students' The Atlantic (Boston, MA, 19 June 2013), https:/www.theatlantic.com/ business/archive/2013/06/do-unpaid-internships-lead-to-jobs-not-for-college-students/ 276959/, accessed 30 March 2021.

30 Cullinane and Montacute (n 1) 47.
} 


\subsection{THE LEGAL IMPLICATIONS OF THE MYTH OF THE (PRIMARY) BENEFICIARY}

In the UK and the USA, the insight that interns are the primary beneficiary of their training has been a crucial element in denying them access to employment rights, including the minimum wage.

The origins of the myth are located in the US Supreme Court decision, Walling $v$ Portland Terminal Co, ${ }^{31}$ according to which, individuals who were trained for a position of brakeman over seven or eight days were not entitled to minimum wage or maximum hour protection under the Fair Labor Standards Act 1938 (FLSA). The Court's rationale was that the railroad company received no 'immediate advantage' from the work performed by the trainees, whereas the latter were receiving free training, for their own benefit. ${ }^{32}$ It accepted that, all else being equal, these trainees would have been entitled to employee status, but qualified the general status by stating that the term 'to employ' in the FLSA was 'not intended to stamp all persons as employees who, without any express or implied compensation agreement, might work for their own advantage on the premises of another'. ${ }^{33}$

As James Brudney explains in Chapter 10 this volume, the Walling decision, and the 'primary beneficiary' test which is at its core, remain influential to this day. In 2010, its principles were 'codified' through a six-prong test by the American Department of Labor. ${ }^{34}$ Moreover, in recent years, the American courts have taken an even more flexible (pro-employer) approach, removing the requirement that an internship be tailored to benefit the participant, and holding that, even when 'the employer receives an immediate advantage from the interns' work', ${ }^{35}$ the interns may not be considered employees.

Turning to the UK, it is interesting to note that the seminal case Daley $v$ Allied Suppliers ${ }^{36}$ resides in the grey area between back-to-work programmes and business-driven internship schemes. In Daley, the scheme was organized by the Manpower Services Commission as part of the Youth Opportunities Programme (YOP). While the claimant was not required to take part in the scheme as a condition of the receipt of benefits, the involvement of the state agencies was far more extensive than in laissez-faire cases of open-market

\footnotetext{
Walling v Portland Terminal Co 330 US 148 (1947).

Ibid 152-3.

Ibid 152 (emphasis added).

34 US Department of Labor, Wage and Hour Division, Fact Sheet \#71: Internship Programs under The Fair Labor Standards Act (DOL 2010).

35 Glatt v Fox Searchlight Pictures, Inc. 791 F 3d 376, 383 (2nd Cir, 2016); Wang $v$ Hearst Corp 877 F 3d 69 (2nd Cir, 2017).

36 [1983] IRLR 14.
} 
internships. The Employment Appeal Tribunal held that a trainee under the YOP could not proceed in her claim for race discrimination since, even if there was a contract, it was one for training, and not a contract of employment. Here too, the dividing line between the two rested on the primary purpose of these schemes being to benefit the participant, and not the employer. At the time, Mark Freedland argued that the administrative YOP and the judicial decisions which governed it created 'a kind of second-class employment citizenship in which the young people concerned engage in work for employers without the benefit of the structure of employment protection legislation which applies to other workers' ${ }^{37}$ Similar concerns were raised regarding the 1988 Employment Training Scheme..$^{38}$

The Daley reasoning was recently followed when the Employment Appeal Tribunal (EAT) ruled that a British cyclist was not employed by the British Cycling Federation 'since what the Claimant was doing was not "work" at all in this context' ${ }^{39}$ Citing and agreeing with the Employment Tribunal (ET), the EAT stated that 'far from this being an arrangement where any service is performed by the Claimant for the Respondent, it was "a contract where services are provided to the Claimant". ${ }^{40}$ Why was the claimant not engaged in 'work'? The answer lies in the 'dominant purpose' test. The test was noted in the ET's decision as helpful when seeking to distinguish a contract of employment from a contract for training ${ }^{41}$ and was discussed more extensively by the EAT. ${ }^{42}$ However, while both tribunals spend some time explaining why the dominant purpose could be relevant in distinguishing the two contract types (employment and training), they offer very little in terms of indices that would enable an observer to scrutinize such a decision. It seems that the tribunal is content to make this type of decision based on its own intuition as to what the relationship 'looks like'. This notion gains support via the EAT's agreement with the respondent's submission that 'the Agreement was a contract for the provision of services by the Respondent to the Claimant, and not the other way around, "feels right". 43

37 Mark Freedland, 'Labour Law and Leaflet Law: The Youth Training Scheme of 1983' (1983) 12 Indust LJ 220, 230.

38 Nick Wikeley, 'Training for Employment in the 1990s' (1990) 53 MLR 354, 365-6.

39 Varnish v British Cycling Federation UKEAT 0022/20/LA(V) (14 July 2020), para 42 ('Varnish EAT').

40 Ibid.

${ }^{41}$ Varnish v British Cycling Federation, Case 2404219/17 (Employment Tribunal, 16 January 2019) paras 256-257.

42 Varnish EAT (n 39) paras 59-66.

43 Ibid para 53. 


\subsection{LEGAL AND NORMATIVE PERSPECTIVES}

Apart from lacking empirical foundations, as already noted, the reasoning employed by the UK and US courts may be criticized on legal, analytic and normative grounds. First, from a legal perspective, we may ask where this test, which focuses on the identification of benefits, derives from. In the USA, the FLSA explicitly empowers the Secretary of Labor to regulate the incorporation of '[1] earners, apprentices, and messengers' and to issue certificates on the basis of those regulations so they will be entitled to 'such wages lower than the minimum wage'. ${ }^{44}$ However, notwithstanding this general power, it is abundantly clear that not only did the statute not dictate this problematic test, but neither did the Secretary of Labor. It was the courts' decision to do so, thus denying employment rights to those who would otherwise be entitled to them. ${ }^{45}$

However, while in the US there is at least some general power to address the situation of 'learners, etc' in respect of minimum wage and hours worked, no such provision exists in British statutes. Presumably, then, we would fall back on the employment tests, which distinguish an employee (and worker) from someone who is self-employed. Yet, it would seem that the main purpose of this test is to deny employment status to those who, if not for the test, would have gained the relevant status and rights. In the UK, this is actioned without statutory authorization.

Second, analytically, we may question whether this dichotomy between benefits for the company (= work) and activities for the benefit of the worker (= not work) holds in general. Paul Budd offers the example of Jake, who is hired as an unpaid intern by a record label to perform administrative duties. He does not gain much from his role (making coffee and organizing files) but is overjoyed by his weekly, five-minute encounters with Mick Jagger, when the latter comes into the office for meetings. ${ }^{46}$ Would that be a sufficient 'benefit' to Jake to remove him from the scope of employment law protection? In addition, take the case of Daniel, a first-year lawyer in a blue chip law firm. Daniel is trying his best to cope with the work, but is simply overwhelmed, and is a poor employee. However, at the end of the first year he has gained numerous skills, some general (punctuality, proofreading, writing and research), some related to the sector (operating a case management system, attracting and retaining clients) and some related to the particular firm. The firm may decide

\footnotetext{
44 Fair Labor Standards Act 193829 USC s 214(a) (2012).

45 Solis (n 16) 529.

46 Paul Budd, 'All Work and No Pay: Establishing the Standard for When Legal, Unpaid Internships Become Illegal, Unpaid Labor’ (2015) 63 Kansas LR 451, 478.
} 
to discontinue his employment, but would it be reasonable to say that, as he benefited from the work more than the firm did, he should be seen as a trainee? Such a conclusion would seem far-fetched. More generally, to drive the point home, we can turn to the position of the business sector during congressional hearings prior to the enactment of the FLSA in 1937. Mr Lane, an industry executive, expressed the concern that workers who start off in the furniture business would be paid as much as a seasoned worker, since the 'average beginner ... is for the first 3 months ... an expense rather than an asset; then the next 3 months he might be worth the room he is taking up, part of which we are paying him, and then after that he becomes valuable to us' ${ }^{47}$

Normatively, this argument makes sense only under a neoliberal paradigm which suggests that regulation should work only to the benefit of business. For it is not as if, when the employee becomes more proficient and the employer is able to charge a higher rate of billable hours for the employee's work, the employee receives compensation that correlates with that increase. This refutes the premise that the person's compensation should, at any given time, be commensurate to the benefit derived from the person's work. The consequences of this type of logic are present in an American case, McLaughlin, ${ }^{48}$ in which the majority accepted the claim that the men who had to undertake a week of 'exposure to tasks' were entitled to the minimum wage. During that week, they worked between 50 and 60 hours, loading and delivering food, and stockpiling vending machines. It was clear from the evidence that they learned very little and, in effect, performed manual labour, relieving other drivers from work. All routemen who took part in the 'orientation' were then 'hired' as drivers. Yet, the minority judge in the case still sought to deny the claim, reasoning that while the participants learned skills that had 'practically no transferable usefulness', this was 'of little significance' ${ }^{49}$ It was enough that they 'learned to interact with store managers' and 'complete some of the paperwork'. This is a clear example of the length someone (a judge) can reach to find a 'benefit' that is sufficient to deny access to basic rights.

The reverse case, which only sheds further light on the subjectivity of the test, and its ideological underpinnings, together with the strong connections between internships and workfare schemes, may be observed in the Archie case. ${ }^{50}$ Judge Sotomayor (as she was then) followed the Walling rationale, and found in favour of the plaintiffs, while acknowledging that the programme provided participants (individuals who were formerly homeless) with skills and

\footnotetext{
47 Fair Labor Standards Act of 1937: Joint Hearings on S 2475 and HR 7200 before the SCom on Educ \& Labor and the HR Comm on Labor, 75th Cong 481 (1937).

48 McLaughlin v Ensley 877 F 2d 1207, 1209 (4th Cir, 1989).

49 Citing Donovan v American Airlines 686 F2d 267 (5th Cir, 1982).

50 Archie (n 21).
} 
work opportunities to which they would not otherwise have access. However, since the work was not supervised, and the level of training was not high, the benefits to the claimant were minimal. This is a high bar, which is not routinely found, for the participants' benefit. Turning to the employer's benefit, Sotomayor found a strong factor was that participants regularly replaced employees on shifts, and that running the scheme was a prerequisite to win a contract with the New York City Council.

Here we find a clear-eyed, realist outlook: it should not be difficult to find benefits on both sides of internship and work participation schemes. Otherwise, we would imagine, interns and perhaps WPs, and surely businesses, would not take part. These benefits are, at times, tangible (a track to work, on one side; free labour, on the other) and sometimes less tangible (skills and reputation). In some sense, these benefits are incommensurable. Who can say, in the abstract, that the skills gained for interns in general are more important than the benefit of choosing the best prospects for businesses?

Moreover, viewing the benefit of work for the worker as an impediment to employment status would seem to contrast with the 'lifelong learning' slogan, which has become central in European Union social policy, dominates the European discourse on social policy reform, and implies the importance of the worker's personal development, thus normatively incorporating work, education and training. ${ }^{51}$ Indeed, we may enquire whether employers should reconsider their obligations to pay full-time employees who are sent for, say, a week-long training programme on new software or to perfect managerial approaches. It is clear that at the time of the training the employer does not benefit from it, and the employees are, by far, the prime beneficiaries (at least, that is the intention). It is not enough, it should be clear, to say that the employer assumes that the gains will be evident in the future, for that is also the case with interns and trainees.

\subsection{WHERE TO GO FROM HERE?}

The 2018 Sutton Trust report focuses on the approaches towards, and conditions of, internships; but it also notes that 61 per cent of graduate respondents did not take up an internship and, of them, 40 per cent (almost 24 per cent of the whole sample) explained that the reasons for doing so included an inability to afford an unpaid internship in a city. ${ }^{52}$ Unsurprisingly, these figures suggest

51 For example, see Lifelong Learning Programme (2007-2013) Decision 1720/2006 EC of the European Parliament and the Council of 15 November 2006, [2006] OJ L327/45.

52 Cullinane and Montacute (n 1) 27. 
that unpaid internships present a significant entry barrier to some occupations, and thus to social mobility (in respect of interns) and diversity (in respect of business).

Both internships and work participation schemes highlight a growing trend towards the legitimacy of free labour, and the supposed need to submit to the cries of businesses which claim that imposing labour rights on these schemes would undermine their viability, in a way that would harm the participants. As a general claim, this is not new, but can be tracked at least to the beginning of the twentieth century. So, a historical perspective would probably view this trend as retrograde, another neoliberal attempt to reverse decades of expanding the scope of labour law and regulation. What can be done in response?

In recent years, legislation, case law and scholarship have all, to different degrees, challenged the strict boundaries that constrict statutory employment protection to only some workers. This path, originally identified by Bob Hepple, ${ }^{53}$ was trail-blazed by Mark Freedland, ${ }^{54}$ and later in conjunction with Nicola Kountouris. ${ }^{55}$ The new project posits the personal work relationship as the central category in labour law, thus doing away with the binary dichotomy between the contract of service and the contract for services. A similar approach suggests that, when assessing statutory protection, we must recognize that 'each piece of legislation has its own purpose, which corresponds with the general values that labour laws are aimed to protect and promote'. ${ }^{56}$ Following this approach, it may be suggested that equal protection legislation, working time or pay measures, for example, were intended to protect individuals precisely in the position of WPs and trainees. However, the prominence of the dominant purpose test in denying employment status to interns may give us pause before moving to quickly embrace it.

Legislation has played a role in this trend as well. This is made clear in the UK, first and foremost by the fact that the Employment Rights Act 1996 includes the apprenticeship contract within the contract of employment. ${ }^{57}$ While the traditional definition of apprenticeship would suggest that WPs do not fall within its boundaries, it may also be suggested that the substantive

53 Bob Hepple, 'Restructuring Employment Rights' (1986) 15 Indust LJ 69, 74.

54 Mark Freedland, 'From the Contract of Employment to the Personal Work Nexus' (2006) 35 Indust LJ 1; Mark Freedland, 'Application of Labour and Employment Law Beyond the Contract of Employment' (2007) 146 Int Lab Rev 3.

${ }_{55}$ Mark Freedland and Nicola Kountouris, 'Employment Equality and Personal Work Relations: A Critique of Jivraj v Hashwani' (2012) 41 Indust LJ 56.

56 Guy Davidov, 'Re-Matching Labour Laws with Their Purpose' in Brian Langille and Guy Davidov (eds), The Idea of Labour Law (OUP 2011) 180-81. See also Guy Davidov, 'A Purposive Interpretation of the National Minimum Wage Act' (2009) 72 MLR 581; Zatz (n 14) 377.

57 Employment Rights Act 1996 s 230(1). 
distance between the two categories does not merit the all (apprentice as employee) or nothing (WPs and trainees) legal conclusion. This position is strengthened with the formal introduction of 'worker' as an intermediate category, between the self-employed and the employee; and with the 'bold and radical' ${ }^{58}$ extension of the continuum in the scope of the anti-discrimination laws of the 1970s, which (in the language of the Equality Act 2010) cover all those under a 'contract personally to do work' ${ }^{59}$ Moreover, legislation has expanded the scope of protective rights to trainees in areas such as health and safety, working time and, perhaps, equal treatment. ${ }^{60}$ The 2018 Sutton Trust report follows this line by recommending that unpaid internships, or training schemes, could last up to four weeks. This is one, partial, solution to the problem. It does not, however, resolve the more challenging problem, which is that, under the pretext of benefiting individuals, businesses are gaining increasing access to free labour.

58 Paul Davies and Mark Freedland, 'Labor Markets, Welfare and the Personal Scope of Employment Law’ (1999) 21 Comp Lab L \& Pol J 231, 234.

59 Equality Act 2010, s 83(1).

60 Respectively: Health and Safety (Youth Training Scheme) Regulations SI 1983/1919, reg 3; Working Time Regulation 1998, reg 42; Equality Act 2010, s 83(2) (a). 